\title{
Water stress and triclopyr on clopyralid efficacy in honey mesquite
}

\author{
ANDREA R. ROCHE, RODNEY W. BOVEY, AND SCOTT A. SENSEMAN
}

Authors are Analytical Chemist, BASF Corp., Agricultural Research Center, 26 Davis Drive, Research Triangle Park, N.C. 27709-3528; Adjunct Professor Department of Rangeland Ecology and Management, Texas A\&M University, College Station Tex., 77843-2126; and Associate Professor, Department of Soil and Crop Sciences, Texas A\&M University, College Station, Tex. 77843-2474.

\begin{abstract}
Water stress may affect herbicide efficacy in herbaceous and woody plants. Chamber studies were conducted to evaluate the influence of water stress $(-1.3$ to $-2.8 \mathrm{MPa})$ and triclopyr on the absorption and translocation of clopyralid in greenhouse-grown honey mesquite (Prosopus glandulosa Torr.). Xylem water potential was determined in honey mesquite at time of herbicide application. Absorption and translocation of clopyralid was determined at low (-1.3 MPa), medium $(-2.2 \mathrm{MPa})$, and high $(-2.8$ MPa) water stress at $4 \mathrm{~h}$ after application for 1.5-mo-old plants, while only translocation was determined at either a low $(-1.4$ or $-1.6 \mathrm{MPa})$ or a high $(-2.4 \mathrm{MPa})$ water stress treatment at 24 hours after herbicide application for 3-mo-old plants. Water stress did not affect $(P<0.05)$ absorption or translocation of clopyralid alone in either study. With 1.5-mo-old plants, the addition of triclopyr to clopyralid increased $(P<0.05)$ clopyralid absorption in leaves at low $(63 \mu \mathrm{g})$ and medium $(54 \mu \mathrm{g})$ water stress compared to high water stress $(33 \mu \mathrm{g})$ but did not affect (P $>0.05$ ) translocation at 4 hours after application. On 3-mo-old plants, triclopyr decreased $(P<0.01)$ clopyralid translocation 24 hours after treatment at high water stress. The reasons for reduced uptake and 24 hours post-treatment translocation of clopyralid when applied with triclopyr at high water stress are unclear, but have implications for field applications.
\end{abstract}

Key Words: Prosopis glandulosa, herbicide, growth chamber, xylem water potential, gas chromatographic analysis

The monoethanolamine salt of clopyralid (3,6-dichloro-2pyridinecarboxylic acid) is a highly effective herbicide for honey mesquite (Prosopis glandulosa Torr.) control when used alone or in mixtures with the butoxyethyl ester of triclopyr $\{[(3,5,6-$ trichlor-2-pyridinyl) oxy]acetic acid $\}$ (Bovey et al., 1988, Bovey and Whisenant 1991, Jacoby et al. 1981). Davis et al. (1968) studied the effect of water stress on two other auxin-type herbicides, picloram (4-amino-3,5,6-trichloro-2-pyridinecarboxylic acid) and 2,4,5-T [(2,4,5-trichlorophenoxy)acetic acid]. They found that water stress reduced foliar uptake of picloram but not 2,4,5-T in honey mesquite. However, water stress sufficient to slow growth markedly reduced the translocation of both herbicides. Clopyralid, however, may be less sensitive to water stress

\section{Resumen}

El estrés hídrico puede afectar la eficacia de los herbicidas en las plantas herbáceas y leñosas. Se condujeron estudios en cámaras para evaluar la influencia del estrés hídrico ( -1.3 to -2.8 MPa) y el triclopir en la absorción y translocación de clopiralid en mezquite (Prosopus glandulosa Torr.) desarrollado en invernadero. El potencial del agua del xilema se determinó en el mezquite al momento de la aplicación del herbicida. La absorción y translocación del clopiralid se determinó $4 \mathrm{~h}$ después de la aplicación en plantas de 1.5 meses de edad sujetas a un estrés hídrico bajo (-1.3 MPa), medio (-2.2 MPa) y alto (-2.8 MPa), mientras que en plantas de 3 meses de edad, sometidas a estrés hídrico bajo (-1.4 or -1.6 MPa) o alto (-2.4 MPa), solo se determino la translocación 24 h después de la aplicación. En ningún estudio estrés hídrico afectó $(P<0.05)$ la absorción o translocación del clopiralid aplica solo. En plantas de 1.5 meses de edad, la adición de triclopir al clopiralid incrementó $(P<0.05)$ la absorción de clopiralid en los niveles de estrés hídrico bajo (63 $\mu \mathrm{g})$ y medio $(54 \mu \mathrm{g})$ comparado con el estrés hídrico alto (33 $\mu \mathrm{g})$, pero no afectó $(\mathrm{P}>0.05)$ la translocación a las $4 \mathrm{~h}$ después de la aplicación. En plantas de 3 meses de edad, en el tratamiento de estrés hídrico alto, el triclopir disminuyó $(\mathrm{P}<0.01)$ la translocación del clopiralid 24 h después de la aplicación. Las razones para la reducida absorción y la translocación del clopiralid $24 \mathrm{~h}$ después de tratadas los plantas, cuando se aplica con triclopir, no son claras, pero tienen implicaciones para las aplicaciones en campo.

since it has been effective on honey mesquite during periods of drought. Bovey and Meyer (1986) detected high clopyralid concentrations in stem phloem and xylem when applications were made during drought or fall months. Kloppenburg and Hall (1990a) found that the absorption and translocation of the acid and ester formulations of clopyralid were not reduced in water stressed wild buckwheat (Polygonum convolvulus L.) but absorption of the monoethanolamine and potassium salt formulations were reduced.

The objectives of this study were to determine the effect of plant water stress on the absorption and translocation of the monoethanolamine salt of clopyralid alone and in mixtures with the butoxyethyl ester of triclopyr in greenhouse-grown honey mesquite. 


\section{Materials and Methods}

\section{Growth environment}

Honey mesquite were grown from seed in the greenhouse under natural light in pots (12.7-cm diam x 12.7-cm deep) containing a mixture of Bleiblerville clay (fine montmorillontic Udic Pellusterts), sand, and peat moss $(1: 1: 1, \mathrm{v} / \mathrm{v} / \mathrm{v})$ from March to June 1990. Daytime temperature was $35^{\circ} \mathrm{C}$ and night temperature was $25^{\circ}$ C. Two plants were grown per pot, and each had a single woody stem. Plants treated at $1.5-\mathrm{mo}$ old averaged $20-\mathrm{cm}$ tall with approximately 8 to 10 leaves per plant. Plants treated at 3-mo old averaged $36-\mathrm{cm}$ tall with approximately 17 leaves per plant. Pots were watered daily to saturation.

Plants were transferred to a growth chamber 2 weeks prior to initiating water stress. Chamber temperature was set at a day/night regime of $35 / 30^{\circ} \mathrm{C}$ with a 16 hour day length and relative humidity of $75 \%$. Light irridiance of the $\mathrm{Na} / \mathrm{Hg}$ lamps ranged between 600 to $700 \mu \mathrm{mol} \mathrm{m}-2 \mathrm{sec}^{-1}$ at the plant apex. Water content of the soil at field capacity was determined by weighing the pots after watering to saturation and allowing the pots to drain.

\section{Stress measurements}

Xylem water potential in the honey mesquite was determined by the Scholander apparatus (Scholander et al. 1965). A separate batch of plants were grown along with the test plants to establish water stress categories. Water was withheld from selected sets of plants at staggered times coincidentally with selected sets of the test plants. Various plants were measured for xylem potential from these selected sets of extra plants until a clear separation of water stress categories emerged. At the time of treatment, 1 of the 2 plants in each pot was cut with a razor blade $1 \mathrm{~cm}$ from the soil level. The cut stem was inserted through the lid of the pressure bomb with the cut end exposed to detect negative hydrostatic pressure in the xylem of honey mesquite. Stem diameter varied from 1.5 to $2.0 \mathrm{~mm}$ in 1.5 -mo old plants to 3 to $4 \mathrm{~mm}$ in 3 -mo old plants. The pressure at which liquid first wet the cut surface was recorded. Based on these measurements, 3 stress categories were created that represented low $(-1.3 \mathrm{MPa})$, moderate $(-2.2 \mathrm{MPa})$, and high (-2.8 MPa) water stress. Each pressure stress category represented the mean xylem potential $\pm 0.2 \mathrm{MPa}$. The average xylem potentials for each stress category ranged from -1.3 to $-2.8 \mathrm{MPa}$.

\section{Absorption and Translocation 4 hours After Herbicide Application}

The paired, uncut honey mesquite plants (1.5-mo old) in every pot were treated with $60 \mu \mathrm{g}$ plant $^{-1}$ of the monoethanolamine salt of clopyralid in $20 \mu$ l aqueous solution or $60 \mu \mathrm{g}$ plant $^{-1}$ of clopyralid plus $20 \mu \mathrm{g}$ plant $^{-1}$ of the butoxyethyl ester of triclopyr. Commercial formulations were used. The final treating solutions contained $0.025 \%$ $(\mathrm{v} / \mathrm{v})$ surfactant $^{1}$. Surfactant concentration of $0.025 \%$ had little biological activity but was necessary for application of the aqueous solution on the leaf cuticle. Herbicides were applied to the two youngest mature leaves at the apex in $10 \mu \mathrm{l}$ aqueous solution (30 $\mu$ g clopyralid) leaf ${ }^{1}$ of a plant that consisted of approximately 8 to 10 leaves. Honey mesquite seedlings were treated at each stress category based on xylem potential readings as described previously.

Plants were harvested 4 hours after treatment. Samples included washed treated leaves, treated leaf washes, and stem which included the entire plant minus treated leaves and roots. The leaf wash was accomplished by washing the detached leaves 2 times in $50 \mathrm{ml}$ basic water $\left(1 \mathrm{ml}\right.$ concentrated $\mathrm{NH}_{4} \mathrm{OH} 1$ liter $^{-1}$ distilled $\mathrm{H}_{2} \mathrm{O}$ ) for $30 \mathrm{sec}$.

To extract clopyralid from plant samples, samples were ground in a Waring blender with acidified acetone $[(0.5 \mathrm{ml}$ $\mathrm{HCl}$ liter $^{-1}$ acetone and water mixture (7:1 $\mathrm{v} / \mathrm{v})]$. Samples were then filtered through a Büchner funnel and $5 \mathrm{ml} \mathrm{NH} \mathrm{NH}_{4} \mathrm{OH}$ were added to the filtered solution.

The acetone was evaporated at room temperature and the $\mathrm{H}_{2} \mathrm{O}$ fraction was adjusted to $\mathrm{pH} 12$ with concentrated $\mathrm{NH}_{4} \mathrm{OH}$ and extracted once with ether. The ether fraction was discarded, and the $\mathrm{H}_{2} \mathrm{O}$ fraction was adjusted to $\mathrm{pH} 2$ with $\mathrm{HCl}$ and saturated with approximately 12 $\mathrm{g}$ of $\mathrm{NaCl}$ to assist in the extraction. This fraction was then extracted 3 times with $50 \mathrm{ml}$ of ether. Ether fractions were passed through an anhydrous $\mathrm{Na}_{2} \mathrm{SO}_{4}$ column to remove moisture, then combined and completely dried. A $50-\mathrm{ml}$ portion of the leaf wash was adjusted to $\mathrm{pH} 2$ with $\mathrm{HCl}$, saturated with $\mathrm{NaCl}(12 \mathrm{~g})$ and extracted in the same manner as the $\mathrm{H}_{2} \mathrm{O}$ fraction. A butyl

${ }^{\mathrm{I}}$ Surfactant WK (trimethylnonylpolyethoxyethanol) E.I. duPont de Nemours and Co., Inc., Walkers Mill. Barley Mill Plaza, Wilmington, Del. 19898. ester derivative of the clopyralid was formed by adding $1 \mathrm{ml} \mathrm{1-butanol}$ and 6 drops $\mathrm{H}_{2} \mathrm{SO}_{4}$ to the residue and heating for $30 \mathrm{~min}$ in boiling water (Cotterill 1978). The mixture was cooled and $20 \mathrm{ml}$ $\mathrm{H}_{2} \mathrm{O}$ and $5 \mathrm{ml}$ hexane were added to the test tube. The mixture was shaken for 1 $\mathrm{min}$, and the hexane layer was dispensed.

The hexane fraction was analyzed by a gas chromatograph (GC) using a 2-m long glass column packed with $3 \%$ OV 210 on 80 to 100 mesh Supelcoport ${ }^{2}$. The GC was equipped with an electron capture detector and $\mathrm{GC}$ settings were: column $-160^{\circ} \mathrm{C}$, injector $-290^{\circ} \mathrm{C}$, and detector $-300^{\circ} \mathrm{C}$. Herbicide concentration was determined by comparing samples to a standard of known concentration. Treating solutions were also analyzed by preparing a derivative of a $10-\mu 1$ aliquot. Percent recovery for the entire procedure was also determined by fortifying untreated plant samples with known amounts of clopyralid (3 $\mu \mathrm{g}$ and $30 \mu \mathrm{g}$ ). Clopyralid recovery was approximately $80 \%$ and was easily detected to $0.05 \mu \mathrm{g} \mathrm{g}^{-1}$. Triclopyr was not determined in these experiments because it had been previously determined that it did not interfere in extraction and analysis of clopyralid as determined by analysis of fortified plant material with clopyralid alone and clopyralid with triclopyr.

The experiment utilized a completely randomized design. Four plants were used per replication with 4 replications. The entire experiment was repeated. Data were subjected to analysis of variance (SAS 1989). Means for the herbicide amount $(\mu \mathrm{g})$ and concentration $\left(\mu \mathrm{g} \mathrm{g}^{-1}\right)$ for the 2 herbicide treatments were compared using Fisher's protected LSD at the $5 \%$ level (Steel and Torrie 1980).

\section{Translocation 24 hours After Herbicide Application}

Three-mo-old honey mesquite plants were sprayed with $0.28 \mathrm{~kg} \mathrm{ha}^{-1}$ of the monoethanolamine salt of clopyralid or clopyralid at $0.28 \mathrm{~kg} \mathrm{ha}^{-1}$ plus $0.14 \mathrm{~kg} \mathrm{ha}^{-1}$ of the butoxyethyl ester of triclopyr. Herbicides were applied in water with $0.025 \%$ surfactant $1(\mathrm{v} / \mathrm{v})$ of the spray solution at the equivalent volume of 93.5 liter $^{-1}$ $\mathrm{ha}^{-1}$ with a laboratory spray chamber (Bouse and Bovey 1967). Plant growth environment and water stress measurements were similar to those in previous experiments except that plants were treat-

\footnotetext{
${ }^{2}$ Supelco Inc., Supelco Park, Bellefonte, Penn. 16823
} 
ed at only 2 stress levels: low ( -1.4 or 1.6 $\mathrm{MPa})$ and high (-2.4 MPa). The upper canopy was sprayed while the lower 10 $\mathrm{cm}$ of canopy and stem were protected by fitting split styrofoam cups and cotton over the lower plant and soil surface to prevent herbicide contact. The cup and cotton were removed after spraying. Plants were harvested 24 hours after treatment since previous studies showed that maximum clopyralid translocation occurred by this time (Bovey et al. 1987, 1989, et al. 1990). Plants were analyzed for clopyralid content in the lower canopy only. Three replications with 3 plants per replication were used in a completely randomized design. The entire experiment was repeated. Data were subjected to analysis of variance and means were compared using Fisher's protected LSD at the 5\% level (Steel and Torrie 1980).

\section{Results and Discussion}

\section{Absorption and Translocation 4 hours After Herbicide Application}

Data were pooled for presentation since no interaction between date and treatment were found. Also, there was no herbicide treatment $\mathrm{X}$ moisture stress interaction for leaf wash, treated leaves, or stem. When clopyralid was applied alone, clopyralid amounts were higher in the leaf wash under high $(-2.8 \mathrm{MPa})$ than at low $(-1.3$ $\mathrm{MPa})$ moisture stress levels 4 hours after treatment (Table 1). There was also a higher fresh weight concentration of clopyralid at the high versus low stress level (data not shown). However, there were no differences in clopyralid content absorbed by the treated leaf or translocated to the lower stem.

Clopyralid remaining in the plant tissue represented 63 to $77 \%$ of the original amount applied 4 hours after treatment after adjusting for the percent recovery of the method, however, the roots were not analyzed (Table 1). Data were consistent with other studies that indicated rapid translocation of clopyralid to the lower stem and roots of plants within 4 hours or more after treatment (Bovey et al. 1987, 1988, 1989, 1990; Bovey and Mayeux 1980, Devine and Vanden Born 1985, Kloppenberg and Hall 1990a, O'Sullivan and Kossatz 1984). Although movement is rapid, some clopyralid may be lost by metabolism (Hall and Vanden Born 1988). Devine and Vanden Born (1985) found that after 144 hours, $29 \%$ of the $14^{\circ} \mathrm{C}$ clopyralid was recovered in roots and developing root buds of Canada thistle [Circuim arvense (L.) Scop.] plants. O'Sullivan and Kossatz (1984) using $14^{\circ} \mathrm{C}$-clopyralid in Canada thistle only recovered about $85 \%$ of the radioactivity after harvesting the entire plant 2 days after treatment. Based on this earlier work, the discrepancy in the amount of clopyralid remaining was probably due to translocation to the root tissue within the first 4 hours.

When clopyralid was combined with triclopyr, more clopyralid was detected in the treated leaves at low and medium stress compared to high stress (Table 1). However, no differences occurred in clopyralid recovered among water stress levels in the leaf wash or the amount of clopyralid translocated to the stem 4 hours after application of the clopyralid:triclopyr mixture (Table 1).

Data in this report agree with field research which indicated more clopyralid was detected in leaves when triclopyr was combined with clopyralid $(0.28+0.28 \mathrm{~kg}$ $\mathrm{ha}^{-1}$ ) than when clopyralid was applied alone at $0.28 \mathrm{~kg} \mathrm{ha}^{-1} 4$ hours after treatment (Bovey et al. 1988). After 24 hours, more clopyralid was detected in the upper stem phloem when combined with triclopyr than when applied alone (Bovey et al. 1988).

\section{Translocation 24 hours After Herbicide Application}

Data were pooled for presentation since no date by treatment interaction occurred. However, a herbicide treatment $\mathrm{X}$ mois-

Table 1. Clopyralid detected in leaf wash, treated leaves and stem 4 hours after application of clopyralid or clopyralid + triclopyr mixture on 1.5 mo-old, greenhouse-grown honey mesquite.

\begin{tabular}{lccccccc}
\hline \hline & & \multicolumn{5}{c}{ Plant part } \\
\cline { 3 - 8 } Herbicide & Water & \multicolumn{2}{c}{ Leaf wash } & \multicolumn{2}{c}{ Treated leaves } & \multicolumn{2}{c}{ Stem $^{2}$} \\
& potential & Amount & Conc. & Amount & Conc. & Amount & Conc. \\
\hline \multirow{2}{*}{ Clopyralid } & $(-\mathrm{MPa})$ & $(\mu \mathrm{g})$ & $\left(\mu \mathrm{g} \mathrm{g}^{-1}\right)$ & $(\mu \mathrm{g})$ & $\left(\mu \mathrm{g} \mathrm{g}^{-1}\right)$ & $(\mu \mathrm{g})$ & $\left(\mu \mathrm{g} \mathrm{g}^{-1}\right)$ \\
& 1.3 & $154 \mathrm{~b}^{3}$ & $416 \mathrm{~b}$ & $27 \mathrm{a}$ & $73 \mathrm{ab}$ & $2.6 \mathrm{~b}$ & $1.0 \mathrm{a}$ \\
& 2.2 & $120 \mathrm{ab}$ & $368 \mathrm{ab}$ & $28 \mathrm{a}$ & $78 \mathrm{ab}$ & $2.5 \mathrm{ab}$ & $1.0 \mathrm{a}$ \\
Clopyralid & 2.8 & $222 \mathrm{c}$ & $659 \mathrm{c}$ & $23 \mathrm{a}$ & $69 \mathrm{a}$ & $3.1 \mathrm{~b}$ & $1.4 \mathrm{~b}$ \\
+ triclopyr & & & & & & & \\
& 1.3 & $89 \mathrm{a}$ & $229 \mathrm{a}$ & $63 \mathrm{~b}$ & $165 \mathrm{c}$ & $2.4 \mathrm{ab}$ & $0.9 \mathrm{a}$ \\
& 2.2 & $99 \mathrm{ab}$ & $231 \mathrm{a}$ & $54 \mathrm{~b}$ & $117 \mathrm{~b}$ & $2.3 \mathrm{ab}$ & $0.8 \mathrm{a}$ \\
& 2.8 & $129 \mathrm{ab}$ & $381 \mathrm{ab}$ & $33 \mathrm{a}$ & $101 \mathrm{ab}$ & $1.5 \mathrm{a}$ & $0.8 \mathrm{a}$ \\
\hline
\end{tabular}

Monoethanolamine salt of clopyralid and the butoxyethyl ester of triclopyr applied at $60 \mu \mathrm{g}$ and $20 \mu \mathrm{g}$, respectively, to the 2 youngest mature leaves of each plant. Four plants/replication were treated and 4 replications were included in the study.

${ }^{2}$ Plant minus treated leaves and roots.

${ }^{3}$ Values in columns followed by the same letter are not significantly different at the $5 \%$ level using Fisher's protected LSD. The values represent mean total amounts and concentrations from 4 plants per replication. 
absorbed from either ester or amine formulations and that triclopyr translocation was rapid in greenhouse-grown honey mesquite. As indicated earlier, certain rates of clopyralid plus triclopyr are synergistic in controlling honey mesquite (Bovey and Whisenant 1991), but the benefit of adding triclopyr to clopyralid may not always be attained when plants are under high water stress.

\section{Conclusion}

From these data, we concluded that clopyralid absorption and translocation in honey mesquite plants is not altered by water stress extremes when evaluated 4 or 24 hours after treatment. Data from the field supports these conclusions since high concentrations of clopyralid were detected in upper and basal stem phloem and xylem both 3 and 30 days after treatment during periods of water stress that ranged between -3.1 and $-1.9 \mathrm{MPa}$ during midday (Meyer and Bovey 1986).

In the field, even during periods of high water stress at midday, predawn water stress in honey mesquite may be $<-1.0$ MPa (Meyer and Bovey 1986, Haas and Dodd 1972) and may permit significant clopyralid translocation. In these studies, water stress was constant, and clopyralid uptake and transport was not reduced under high water stress. It is evident that clopyralid is highly stable and mobile within honey mesquite plants. Absorption through the symplast and translocation through the phloem are essential for activity. The uptake of clopyralid has been classified as nonfacilitated diffusion by Devine et al. (1987). An ion-trap mechanism was shown to be responsible for retaining the undissociated herbicide in the cytoplasm. Since clopyralid was reversibly bound, it can easily be moved into the phloem for transport.

The reasons are unclear for reduced uptake of clopyralid when applied with triclopyr at high water stress. This mechanism should be investigated since clopyralid:triclopyr mixtures are sometimes synergistic in controlling honey mesquite plants and similar mechanisms may exist for other weeds and herbicides.

\section{Literature Cited}

Bouse, L. F. and R. W. Bovey. 1967. A laboratory sprayer for potted plants. Weeds 15:89-91.

Bovey, R. W. and H. S. Mayeux, Jr. 1980. Effectiveness and distribution of 2,4,5-T, triclopyr, picloram and 3,6-dichloropicolinic acid in honey mesquite (Prosopis juliflora var. glandulosa). Weed Sci. 28:666-670.

Bovey, R. W. and R. E. Meyer. 1986. Concentration of 2,4,5-T, triclopyr, picloram and clopyralid in honey mesquite (Prosopis glandulosa) stems. Weed Sci. 34:211-217.

Bovey, R. W. and S. G. Whisenant. 1991. Control of honey mesquite with clopyralid, triclopyr, or other clopyralid:triclopyr mixtures. J. Range Manage. 44:52-55.

Bovey, R. W., H. Hein, Jr., and R. E. Meyer. 1983. Absorption and translocation of triclopyr in honey mesquite (Prospsis juliflora var. glandulosa). Weed Sci. 31:807-812.

Bovey, R. W., H. Hein, Jr., and R. E. Meyer. 1988. Phytotoxicity and uptake of clopyralid in honey mesquite (Prosopis glandulosa) as affected by adjuvants and other herbicides. Weed Sci., 36:20-23.

Bovey, R. W., H. Hein, Jr., and F. N. Keeney. 1989. Phytotoxicity, absorption and translocation of five clopyralid formulations in honey mesquite (Prosopis glandulosa). Weed Sci. 37:19-22.

Bovey, R. W., H. Hein, Jr., R. E. Meyer, and L. F. Bouse. 1987. Influence of adjuvants on the deposition, absorption and translocation of clopyralid in honey mesquite (Prosopis glandulosa). Weed Sci. 35:253-258.

Bovey, R. W., H. Hein, Jr., F. N. Keeney, and S. G. Whisenant. 1990. Phytotoxicity and transport of clopyralid from three formulations in honey mesquite. J. Plant Growth Regul. 9:65-69.

Cotterill, E. G. 1978. Determination of 3,6dichloropiclonic acid residues in soil by gas chromatography of the 1-butyl ester. Bull. Environ. Contamin. Toxicol. 15:471-474.

Davis, F. S., M. G. Merkle and R. W. Bovey. 1968. Effect of moisture stress on the absorption and transport of herbicides in woody plants. Bot. Gaz. 129:183-189.

Devine, M. D. and W. H. Vanden Born. 1985. Absorption, translocation and foliar activity of clopyralid and chlorsulfuron in Canada thistle (Cirsium arvense) and perennial sowthistle (Sonchus arvensis). Weed Sci. 35:524-530.

Devine, M. D., H. D. Bestmann, W. H. Vanden Born. 1987. Uptake and accumulation of the herbicides chlorsulfuron and clopyralid in excised pea root tissue. Plant Physiol. 85:82-86.

Haas, R. H. and J. D. Dodd. 1972. Waterstress patterns in honey mesquite. Ecol. 53: 674-680.
Hall, J. C. and W. H. Vanden Born. 1988. The absence of a role of absorption, translocation, or metabolism in the selectivity of picloram and clopyralid in two plant species. Weed Sci. 36: 9-14.

Jacoby, P. W., C. H. Meadors, and M. A. Foster. 1981. Control of honey mesquite (Prosopis juliflora var. glandulosa) with 3,6dichloropiclonic acid. Weed Sci. 29:376-381.

Kloppenburg, D. J. and J. C. Hall. 1990a. Effects of formulation and environment on absorption and translocation of clopyralid in Cirsium arvense (L.) Scop. and Polygonum convolvulus L. Weed Res. 30:9-20.

Kloppenburg, D. J. and J. C. Hall. 1990b. Penetration of clopyralid and related weak acid herbicides into and through isolated cuticular membranes of Euonymus fortunei. Weed Res. 30: 431-438.

Meyer, R. E. and R. W. Bovey. 1986. Influence of environment and stage of growth on honey mesquite response to herbicides. Weed Sci. 34:287-289.

O'Sullivan, P. A. and V. C. Kossatz. 1984. Absorption and translocation of ${ }^{14} \mathrm{C}-3,6$ dichloropicolinic acid in Circium arvense (L.) Scop. Weed Res. 24:17-22.

Statistical Analysis Systems [SAS]. 1989. The SAS System for Windows. Version 6.12. Cary, NC: Stat. Anal. Systems Instit.

Scholander, P. F., H. T. Hammel, E. D. Bradstreet, and E. A. Hemmingsen. 1965. Sap pressure in vascular plants. Sci. 148:339-348.

Steel, R. G. D. and J. H. Torrie. 1980. Principles and Procedures of Statistics, a Biometrical Approach, $2^{\text {nd }}$ Ed. McGraw-Hill Book Co., New York. 